\section{Manual med begrensninger}

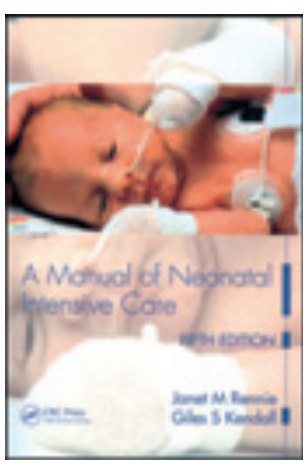

Janet M. Rennie, Giles Kendall

A manual of neonatal intensive care

5.utg. 406 s, tab, ill. Oxon: CRC Press, 2013.

Pris BGP 23

ISBN 978-0-340-92771-7

Denne boken brukes av leger i spesialisering og nyfødtsykepleiere i England og er rettet mot disse. Førsteforfatteren er vel kjent blant norske nyfødtleger som redaktør for Roberton's Textbook of Neonatology, et godt ansett referanse- og oppslagsverk. Begge forfatterne er ansatt ved University College London Hospitals. Det er ingen medforfattere til noen av kapitlene.

Utfordringen ved en slik tilnærming, som tegner seg ganske tydelig når man leser, er at det er få av oss gitt å være helt oppdatert på de mange ulike feltene i nyfødtmedisinen. Ganske mange av kapitlene har derfor et utdatert referanseapparat. Eksempel: I et kapittel på kun to sider om genetiske sykdommer anbefales Smith's Recognizable patterns of human malformation i 1997-utgave, ennskjønt det faktisk kom nye utgaver både i 2006 og 2013. De opplysningene og anbefalingene som gis, er dessverre flere steder preget og hemmet av denne, i hvert fall delvise, utdateringen.

Når en bok har ordet «manual» i tittelen, forventer jeg at den er organisert på en slik måte at det er lett å finne frem til informasjon. Stikkordene blir «lommeformat, didaktisk gjennomtenkt og lett tilgjengelig». Når målgruppen i stor grad er travle utdanningskandidater, er det problematisk at selv ganske sentrale terapeutiske poenger først kommer frem når man leser hele det aktuelle kapitlet fra begynnelse til slutt.

Det er mange oversiktlige og nyttige tabeller, men hvorfor har man valgt det typografiske grepet å sette disse med typer som er mindre og klart blekere, og derfor vanskeligere å se, enn hovedteksten? Når det i tillegg er få og i og for seg ikke spesielt nyttige illustrasjoner, synes jeg man bommer på målgruppen. Eksempel: Part 5 om prosedyrer og komplikasjoner inneholder kun én eneste figur, en barnefot med markering av hvor det er riktig å stikke når man skal ta kapillære blodprøver. Hvorfor denne figuren er valgt fremfor en rekke andre man kunne hatt større nytte av, er gåtefullt.

Jeg tror A manual of neonatal intensive care kan fungere bedre som en første lærebok for introduksjon til nyfødtmedisinen. Har man tid og anledning til å sette seg ned og lese hvert kapittel i ro og fred fra begynnelse til slutt, har man utvilsomt fătt med seg mye kunnskap når man kommer til siste side. Da er man rede til å lese hele «Roberton», som for øvrig oppgis under overskriften «Further reading» etter mange av kapitlene. Som manual kan jeg ikke anbefale den til yngre kolleger.

Thor Willy Ruud Hansen

Overlege, Nyfødtavdelingen

Kvinne- og barneklinikken

Oslo universitetssykehus

\section{Best som oppslagsverk}

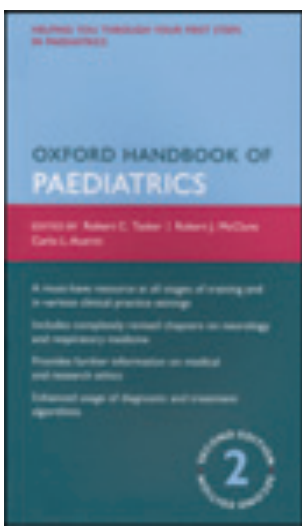

\author{
Robert C. Tasker, Robert J. McClure, \\ Carlo L. Acerini, red. \\ Oxford handbook of paediatrics \\ 2. utg. 1072 s, tab, ill. Oxford: Oxford \\ University Press, 2013. Pris GBP 35 \\ ISBN 978-0-19-960830-0
}

Robert C. Tasker og medforfatterne har skrevet en kompakt og informasjonstung håndbok der målsetningen har vært å destillere ned mer tradisjonelle lærebøker til et verk man kan bruke i den daglige kontakten med pasienter. Målgruppen er leger i spesialisering og spesialister som jobber med generell pediatri.

Boken er bygd over samme lest som den mer kjente Oxford handbook of clinical medicine. Formatet er hendig med sine $10 \times 18 \mathrm{~cm}$, omslaget i plast tåler litt juling og papirkvaliteten er egnet til formålet. For å få plass i frakkelommen må man riktignok være litt hardhendt, da boken har godt over 1000 sider.

31 kapitler omhandler de tradisjonelle medisinske fagfeltene i tillegg til egne kapitler om nyfødtmedisin, ungdomsmedisin, barnekirurgi, genetikk, metabolske sykdommer, sosialpediatri med mer. Teksten er lettlest, med hyppig bruk av punktvis fremstilling, og tabellene er oversiktlige. Her finnes både symptomavsnitt, diagnoseavsnitt og avsnitt om praktiske prosedyrer. Anamnese, kliniske funn, forslag til supplerende undersøkelser, behandling og differensialdiagnoser omhandles, og forfatterne advarer mot klassiske fallgruver.

Boken er etter min mening en blanding av en klassisk metodebok og et oppslagsverk. Styrken er grundigheten og meget gode avsnitt om differensialdiagnoser. Jeg har inntrykk av at boken omtaler det aller meste man kan lure på i en klinisk hverdag, men har hatt problemer med å finne det jeg leter etter. For meg har det vært enklere å lete i kapitteloversikten foran enn å bruke den høyst middelmådige alfabetiske oversikten bakerst.

I Norge har Barnelegeforeningen laget meget gode veiledere i både akutt og generell pediatri. Disse veilederne er skreddersydd etter norske forhold også for utredning og behandling. Jeg synes disse er enklere å finne frem i og oppleves som mer tidseffektive $i$ et travelt akuttmottak.

Oxford handbook of pediatrics er svært grundig, den favner bredt og er faglig oppdatert. Førsteinntrykket preges likevel av at håndboken er lite intuitiv og for tung til vanlig klinisk bruk. Den fungerer betydelig bedre som et konsist oppslagsverk enn som en metodebok, men vil likevel garantert være nyttig om brukeren gir den tid.

\section{Anders Haugom Christensen}

Lege i spesialisering, Barneavdelingen Drammen Sykehus 